\title{
WHAT DOES IT TAKE TO TRAVEL PHILOSOPHICALLY LIGHT? A RESPONSE TO NIELSEN
}

\section{Idil Boran*}

In his reply to criticism raised against his reading of Rawl's constructivist method in light of Rorty's pragmatism, Kai Nielsen defends his position on the basis that it provides the tools for an external defence of liberalism. An external defence seeks to justify a liberal conception of justice in a way that will be acceptable not only to those who have already accepted the core substantive principles of liberal theory, but to those who reject these core principles. This paper assesses Nielsen's proposal and shows that Rortian pragmatism is a limited way of achieving an external defence of liberal political and legal institutions. I propose to develop instead the idea of Kantian constructivism to this end. This discussion also brings to light broader questions about the idea of practical philosophy, and thus pays tribute to the works of John Rawls, Richard Rorty, and Kai Nielsen.

Dans sa réplique à la critique faite de son interprétation de la méthode constructiviste de Rawls à la lumière du pragmatisme de Rorty, Kai Nielsen défend sa position en indiquant quelle offre des outils pour faire une défense externe du libéralisme. Une défence externe cherche à justifier une conception libérale de la justice d'une façon qui sera acceptable non seulement par ceux qui ont déjà accepté les principes importants de fond de la théorie libérale, mais par ceux qui rejettent ces principes de fond. Cet article évalue la proposition de Nielsen et démontre que le pragmatisme de Rorty est une façon limitée d'en arriver à une défense externe des institutions politiques et juridiques libérales. Je propose de développer plutôt l'idée de constructivisme kantien à cette fin. Cette discussion fait aussi ressortir des questions de plus grande envergure au sujet de l'idée de philosophie pratique et rend ainsi hommage aux auvres de John Rawls, Richard Rorty et Kai Nielsen.

\section{INTRODUCTION}

In his writings, Kai Nielsen presents a reading of John Rawls's constructivist method in light of Richard Rorty's pragmatism. ${ }^{1}$ My aim in this paper is to

\footnotetext{
Department of Philosophy, York University. I am indebted to Kai Nielsen for being a true philosophical interlocutor. My arguments in this paper have developed as a result of an ongoing conversation with Nielsen. I also wish to thank him specifically for his comments on an earlier draft of this paper. Additionally, I wish to thank Adam Rawlings for excellent research assistance and insightful comments, and Mo Al-Hakim for helpful suggestions on recent debates on justificatory neutrality.

1 Kai Nielsen, "On there being Philosophical Knowledge" (1990) 56 Theoria 193; Kai Nielsen, "Can there be Justified Philosophical Beliefs?" (1991) 40 Iyyun 235; Kai Nielsen, "Philosophy
} 
examine Nielsen's recent reply to my previous objections that Rawls's views on method are not compatible with Rorty's pragmatism. I have argued that Rawls has a specific vision of how philosophy ought to be done without metaphysics, and that Nielsen's reading of Rawls's method through a Rortian lens distorts this vision. ${ }^{2}$ In a recent essay, ${ }^{3}$ Nielsen brings to the debate some nuanced points. Although he accepts that there are significant methodological disparities, Nielsen argues that Rorty's pragmatism can nevertheless advance our understanding of how questions about justice - especially liberal justice - can be addressed in a way that is genuinely practical and non-metaphysical. Nielsen argues that Rawls seeks a justification of liberal justice that coheres with basic premises of liberalism (such as the commitment to accommodate value plurality). But, for Nielsen, this would be a matter of debate at a roundtable of liberal philosophers already committed to these basic premises and seeking to develop the most plausible way of constructing a theory of justice given these premises. Rortian pragmatism, argues Nielsen, can provide a basis for a different kind of defence: a world-savvy case for liberalism capable of reaching an audience of non-liberals who remain unmoved by liberalism's core principles. ${ }^{4}$ I will assess the plausibility of this proposal.

\section{A QUESTION OF JUSTIFICATION}

Probably one of the most pressing challenges we humans face is how to govern ourselves, not just as individuals (although that, too) but as collectives. How can the legal, economic, and political institutions of society be organized in a way that is not merely efficient but also just? In addressing this issue, one possible approach is to start by identifying what is worthwhile in human life. One could, for example, begin with what is required for human flourishing or for the sort of life that is worth living. Then, based on what it takes to achieve this good life, one could make recommendations on how public institutions should be organized, and what government ought to provide to facilitate the achievement of the good life for its citizens. One could then articulate the sort of responsibilities that fall on citizens for serving this project and how these responsibilities are to be distributed fairly amongst the citizens.

Unfortunately, though initially tempting, this approach is the beginning of a dead-end, as people hold very different views on what human flourishing is and what kind of life is worth living. In some cases, these views may be motivated by

within the Limits of Wide Reflective Equilibrium Alone" (1994) 43 Iyyun 3; Kai Nielsen, "Reply to Richard Rorty" in Michel Seymour \& Matthias Fritsch, eds., Reason and Emancipation: Essays on the Philosophy of Kai Nielsen (Amherst, N.Y.: Humanity Books, 2007)131 [Nielsen, "Reply to Richard Rorty"]; Kai Nielsen, "Reply to Idil Boran" in Michel Seymour \& Matthias Fritsch, eds., Reason and Emancipation: Essays on the Philosophy of Kai Nielsen (Amherst, N.Y.: Humanity Books, 2007) 271 [ Nielsen, "Reply to Idil Boran"].

2 Idil Boran, "Rawls and Carnap on Doing Philosophy without Metaphysics" (2005) 86 Pacific Philosophical Quarterly 459; Idil Boran, "Are Some of the Philosophers in Neurath's Ship Moral Philosophers?" in Seymour \& Fritsch, ibid., 265 [Boran, "Philosophers in Neurath's Ship"].

3 Kai Nielsen, "On There Being Wide Reflective Equilibria: why it is important to put it in plural" (2008) 26 Winsdor Y.B. Access Just. [Nielsen, "Wide Reflective Equilibria"].

4 An earlier articulation of these views is in Nielsen, "Reply to Idil Boran", supra note 1. 
mere personal preferences. For example, someone may simply have a preference for professional scuba diving and may wish to organize his life in the pursuit of this activity. Others, however, may be motivated by more reflective beliefs about human excellence and may wish to identify and pursue their goals in line with those beliefs. These differences suggest that one wholesale understanding of the good cannot easily be identified. Whether it is based on what they want or what they believe, people will hold very different views on what it means to live a good life.

The recognition of a lack of unity over what counts as a good life is an important component of modern liberal political philosophy. For example, Rawls calls these different views "comprehensive views" or "conceptions of the good," which are short terms for "conceptions of the meaning, value and purpose of human life." For Rawls, these views are often metaphysical claims. So, to debate these questions requires engaging in metaphysical speculation of some sort. Such speculation may involve debating what the ultimate good is or what the underlying truth is about the ultimate value in life. ${ }^{6}$

The plurality of these views in society, generally referred to as value pluralism, is an empirical fact that Rawls takes as a given. Rawls, as is well known, is interested in identifying the principles of justice to govern the structure of society. Recognizing the existence of value pluralism in modern societies, he maintains that it is misguided to try to settle metaphysical questions for the purposes of identifying the requirements of justice. Principles of justice, for Rawls, must be derived from something other than a metaphysical view of the good. I will refer to this feature as "the avoidance of metaphysics." Thus, Rawls's inquiry about justice is a qualified one: what would make institutions just, given the reality of value pluralism (and the difficulties involved in settling metaphysical questions)? Are there principles of justice not based on a particular metaphysical theory, which a fashion-conscious scuba diver, an atheist neurosurgeon, and a religious conservative (and many more complex combinations) can all agree to, despite their different conceptions of a good life?

Given this framework of inquiry, three points about Rawlsian theory deserve our attention. First, Rawls's interest in justice is a practical one. For Rawls, justice is not an abstract concept to be clarified through purely theoretical thinking. It is a practical question that should be dealt with in relation to specific circumstances and empirical realities of a given place and time. Thus, when Rawls says that he considers justice only as a "virtue of institutions," he is highlighting this practical attitude. ${ }^{7}$ For Rawls, justice is best understood as a feature of institutions rather than an abstract concept. Value pluralism described above is one such empirical reality to be taken seriously.

Second, Rawlsian theory comprises two levels of justification: (i) the justifi-

5 John Rawls, "The Idea of an Overlapping Consensus" in Samuel Freeman, ed., Collected Papers (Cambridge, Mass.: Harvard University Press, 2001) 421 at 424-425 [Rawls, "Idea of an Overlapping Consensus"].

6 Rawls also recognizes that, in many people's minds, these claims may be motivated by religious doctrines or otherwise by some form of divine or spiritual inspiration.

7 John Rawls, "Justice as Fairness" in Freeman, supra note 5, at 47 [Rawls, "Justice as Fairness"]; John Rawls, A Theory of Justice (Cambridge, Mass.: Harvard University Press, 2001) at 3. 
cation of the avoidance of metaphysics and (ii) the justification of any specific principle of justice that may follow once the rationale for the avoidance is accepted. The former has priority over the latter, in that the construction of liberal principles of justice presupposes an avoidance of particular conceptions of the good. Given this priority, I will refer to the commitment to avoid metaphysical speculations about the good as the "core commitment of liberalism." 8 For Rawls, to the extent that Rawlsian liberalism is a moral theory, this core commitment must itself be motivated by a moral rationale or a sense of justice. ${ }^{9}$ However, the justification of this core commitment is not well developed by Rawls. He is more interested in developing the principles of justice that ought to follow once the core commitment is accepted. ${ }^{10} \mathrm{I}$ will return to this point later.

Third, both his practical attitude toward justice and his willingness to avoid metaphysical debates incite Rawls to confront a whole range of questions about method. To identify principles of justice in a way that avoids metaphysical questions, Rawls develops a method he calls wide reflective equilibrium [WRE]. ${ }^{11}$ This is a coherence-based method of devising principles of justice. This method follows a process in which we start from basic intuitions and weigh them against principles of justice and relevant empirical information, revising each along the way until a point of equilibrium is reached. ${ }^{12}$ In this paper, I will not be concerned with the specifics of this method, but with the idea behind it. Thus, references to WRE will imply the broad methodological framework where a coherence-based method prevails over methods that seek to establish justice on metaphysical theories about the good. I will refer to this general framework as "Rawlsian constructivism."

8 My description of liberalism's core commitment differs from that of other scholars. See e.g. Susan Dimock, "Liberal Neutrality" (2000) 34 Journal of Value Inquiry 189-206 at 190, where she describes liberalism as having three core commitments: (1) that political society is artificial, (2) that the individual is the locus of value, and (3) the recognition that individuals differ in their "values, purposes, ends, interests, commitments, and goals." My account of liberalism's core commitment is limited to (3) and therefore is a minimal one. To include (1) and (2) would commit one to an account of liberalism as a substantive normative theory, which Dimock acknowledges, at 203. This is so because these two claims are substantive claims. Although I recognize that liberalism can be formulated as a substantive normative theory, it can also be a non-substantive theory (and this is what Rawls is seeking to achieve). I will not, in this paper, discuss which of the two might be preferable, but merely discuss the justificatory questions that arise from a more minimalist and non-substantive conception of liberalism.

9 This supposition is clearly articulated in John Rawls, "Idea of an Overlapping Consensus", supra note 5 at 432 .

10 Thus, when he gives reasons for the core commitment, his discussion is usually brief. In John Rawls, "Justice as Fairness" in Freeman, supra note 7, at 395, Rawls writes, we must recognize public agreement on basic questions of religious and moral doctrine as well, as philosophical search for truth about an independent metaphysical or moral order "cannot be obtained without the state's infringement of basic liberties." This for Rawls suffices to establish the rationale for the avoidance of metaphysics, and he moves on to discuss at length the principles that ought to follow once this rationale is accepted.

11 John Rawls, "The Independence of Moral Theory" in Freeman, supra note 5 at 288.

12 See also Norman Daniels, Justice and Justification: Reflective Equilibrium in Theory and Practice (Cambridge: Cambridge University Press, 1996). 


\section{NIELSEN ON WIDE REFLECTIVE EQUILIBRIUM}

In recent years, Nielsen has advanced the thesis that Rawlsian constructivism is compatible with Rorty's general views about philosophy. This proposal faces the obvious objection that Rorty's views about philosophy are fundamentally incompatible with Rawls's views about method. ${ }^{13}$ But Nielsen holds a nuanced position on Rorty's pragmatism, and has recently offered an interesting response to this objection. In order to assess his response, let us briefly examine the debate over Rorty in the context of Rawlsian liberalism.

As is well-known, Rorty has long held the view that there is no universal and objective truth, and that truth claims can only be contextual. ${ }^{14}$ Traditionally, claims Rorty, philosophy consisted of seeking objective and universal truth above historical and contextual particularities. Plato invented philosophy, Rorty writes in a recent article, "by postulating the existence of unchanging ideas." 15 For Rorty, this traditional view of philosophy has implications for moral theory, for the assumption that there must be an absolute truth to be unveiled through the works of reason is taken to entail the claim that there must also be absolute values. ${ }^{16}$ Once revealed, these absolute values can provide moral guidance to people on how to arrange their lives and their institutions. But, says Rorty, there is no such thing as unchanging moral "essences" to be grasped, but "only new ways of describing ourselves and the universe." ${ }^{17}$ For Rorty, this does not undermine moral progress, but redefines it: progress does not involve grasping what is right or wrong in light of absolute values, and instead occurs because people become aware of alternatives. With alternatives at hand, they can imagine a better world. ${ }^{18}$

Nielsen, who is interested in Rawlsian constructivism, has reasons to find Rorty's views congenial. I have started by sketching the basic components of Rawlsian constructivism, and identified a rejection of metaphysics and a concern for practical questions as being two such basic components. Rorty seems to have, at least on the surface, these two points in common with Rawls. First, Rorty re-

13 I have previously raised this objection, see supra note 2.

14 See generally Richard Rorty, Philosophy and the Mirror of Nature (Princeton: Princeton University Press, 1979) [Rorty, Mirror of Nature]; Richard Rorty, "The Priority of Democracy to Philosophy" in Alan Malachowski, ed., Reading Rorty (Basil Blackwell: Cambridge, Mass.: Basil Blackwell, 1990) 279-372 [Rorty, "Priority of Democracy"]; Richard Rorty, "Is Philosophy Relevant to Applied Ethics?" (2006) 16:3 Business Ethics Quarterly 368-380 [Rorty, "Philosophy Relevant to Applied Ethics"]; Richard Rorty, "A Response to Kai Nielsen's Proposal for a Transformation of Philosophy" in Seymour \& Fritsch, supra note 1, 122-130 [Rorty, "Response to Kai Nielsen"].

15 Rorty, "Philosophy Relevant to Applied Ethics", ibid. at 370.

16 Ibid. at 371.

17 Ibid.

18 Although I will get back to this point later on, it is worth noting here that how the world is 'better' is unclear. If there are no absolute values and progress is achieved only by becoming aware of alternatives, what makes a world 'better'? Is it more awareness of alternatives? But then when is awareness of alternatives moral progress? Without an independent sort of value underwriting the sense in which awareness of alternatives makes things better, the claim that this awareness does make things better looks vacuous at best. Special thanks to Adam Rawlings for his insights, which helped to clarify this point. 
jects metaphysics on the basis that it can be of no use for solving concrete problems or for providing guidance on how to govern ourselves, either as individuals or as collectives. Second, Rorty, like Rawls, is decidedly practical-minded. They both want to find genuinely practical solutions to concrete problems.

There is textual evidence to back these considerations. Rorty writes that we moderns "have come to think that there is no single good life for man."19 [emphasis added] We no longer assume, he explains, that there is a shared essence and that knowledge of such essence can help us decide what to do with ourselves. This bears resemblance with Rawls's view that there is no single true conception of the good and that it would be misguided to try to identify the requirements of justice by engaging in metaphysical speculations about the good. Like Rawls, Rorty emphasizes the importance of turning "away from metaphysics in favor of politics. ${ }^{20}$ For Rorty, metaphysics is also not relevant to applied ethics. ${ }^{21}$ Moral philosophy that does not bear on questions about whether and how to change our political and social institutions is pointless. ${ }^{22}$ Again, these statements have a ring of familiarity. Recall that for Rawls the requirements of justice must be constructed on a political (not metaphysical) basis, in relation to concrete political and social institutions.

Still, many will remain unmoved by Nielsen's claim that there exists a commonality between Rorty and Rawls, qualifying this seeming resemblance as being merely superficial. This is because there are significant differences that cannot be overlooked. Although he rejects the idea of philosophy as the search for metaphysical truth, Rawls is interested in developing a theory of justification, as outlined above. By contrast, Rorty adamantly rejects any such endeavour. For Rorty, rejecting metaphysics and embracing a contextualist view should also entail rejecting a theory of justification. Thus, for Rorty, philosophy cannot have a justificatory role.

Stripped of any justificatory role, there remain only two things philosophy can do. One is to engage in some form of Wittgensteinian therapy, showing other (yet unaware) philosophers that the traditional ways of searching for the truth present a futile endeavour. Philosophy, just like therapy, can only be used for diagnosing malfunction and helping to overcome it. But this is a self-referential use of philosophy. What should those who genuinely want to look for ways of improving the world do? For Rorty, there is a second option available to philosophers. They must give up trying to identify what is right or wrong by seeking a timeless moral truth; they must instead look for ways of improving the world by using imagination and narratives. The problem with this endeavour, however, is that it collapses with other disciplines (especially narrative-based ones, such as history, literature, and journalism). What is to differentiate philosophy from those disciplines? For Rorty, there is no differentiation. Philosophy, then, presents no special skill (perhaps other than the aforementioned Wittgensteinian therapy). Anyone interested in improving the world, Rorty concedes, can

19 Rorty, "Philosophy Relevant to Applied Ethics", supra note 14 at 370.

20 Ibid.

21 Ibid. at 373.

22 Ibid. at 375. 
engage in debates on how to make it happen. All one needs, writes Rorty, is "a journalist's nose for a good story, and a novelist's talent at spinning it." ${ }^{\prime 23}$

Rawls, of course, never reaches this position about method. For Rawls, the removal of metaphysics must give rise to a theory of justification. And that theory, in his view, is Kantian constructivism in ethics. Rawls is of the view that, if adequately developed, this method of justification can be a useful tool to make plausible recommendations for legal, economic, and political organization of society, with a genuinely practical promise and no metaphysical baggage. But it is nonetheless a specific method, whose refinement, for Rawls, is itself a philosophical project. In sum, although they both have similar starting points, Rawls and Rorty seem to move in altogether different directions.

Nielsen is aware of these disparities. But, against his critics, Nielsen maintains that Rorty's views can nevertheless provide a productive perspective in refining Rawls's views on method. Nielsen points out that WRE is not a monolithic method, but has multiple uses. He then claims that Rorty's pragmatism is compatible with at least one of them.

\section{INTERNAL AND EXTERNAL JUSTIFICATIONS OF LIBERAL JUSTICE}

What are the multiple uses of WRE? In his recent paper published in this Yearbook, ${ }^{24}$ Nielsen distinguishes between internal and external justifications of principles of liberal justice and states that WRE can be used at both levels of justification. He then clarifies that Rawls is interested in formulating an internal justification of liberal principles. His goal, Nielsen tells us, is to show that political liberalism "hangs together," and that it is a consistent and coherent view of justice. ${ }^{25}$ But whether it hangs together is a separate question from whether or not it is a plausible framework to think about social justice in the first place. In other words, the question of coherence concerns those who have already accepted the general framework of liberal justice and who look for the best way of constructing a liberal theory. Having already accepted the core commitment of liberalism, they want to see which formulation of liberal theory is most coherent. This type of investigation is internal in that it appeals to an audience of those who are moved by liberalism's core commitment.

But there is a second, external, audience consisting of those who do not accept the core commitment of liberal theory. Some, for example, are suspicious of the commitment to accommodate value pluralism on the basis that such accommodation promotes substantive liberal values, such as the primacy of individual liberty. ${ }^{26}$ To illustrate, let us suppose, as Nielsen does, an external objector who

23 Ibid. at 378

24 Nielsen, "Wide Reflective Equilibria", supra note 3.

25 Ibid.

26 Various categories of non-liberals can be identified. Susan Dimock in supra note 8 at 203, defines two well-known categories as follows: (1) communitarians, who "deny that individuals are the sole locus of value" and (2) conservatives, who "deny that individuals are the sole locus of value and that value is ultimately determined by the commitments of individuals as they see them." These categories are not clear-cut. Variations can be provided and in some cases they can also 
holds non-liberal and conservative values. Let us refer to this hypothetical objector as 'Nielsen's conservative sceptic' ${ }^{27}$ and assume that he opposes substantive liberal values, such as individual liberty, on grounds that he finds them offensive. He finds them to be, say, corrupting. On the basis that he rejects these substantive liberal values, he rejects proposals of liberal justice. Instead, he wants to live his life by finding satisfaction and pleasure in hierarchical family structures and community values, where the community as a whole is viewed as a locus of agent-neutral values.

Can a justification of liberal justice be provided to an external audience, such as this conservative sceptic? Nielsen maintains that Rorty's pragmatism is promising for such external justification. In order to see how this can be achieved, Nielsen prescribes a nuanced reading of Rorty's pragmatism. Although Rorty maintains that philosophy can have no justificatory role, argues Nielsen, it does not follow that no justification can be provided. What Rorty rejects is the view that such justification is the outcome of a grand theory about truth and morality. In contrast, he accepts that it should be possible to provide a justification, but this justification has to be a pragmatic one. ${ }^{28}$

\section{CAN NIELSEN HAVE HIS RAWLS AND RORTY TOO?}

With this in mind, Nielsen argues that, if equipped with Rorty's pragmatism, liberalism can be defended against an external audience while acknowledging that there is no "perspective-less" ahistorical standpoint. ${ }^{29}$ Liberal theorists, such as Rawls, are keen on a neutral justification of liberalism. To external critics, rather than being genuinely neutral, such a justification introduces substantive liberal values (such as individualism or individual freedom). For these critics, under the guise of liberal neutrality, these substantive liberal values are imposed on people who do not share them. By contrast, in a Rorty-style defence, it would be openly recognized that the justification of liberalism comes from a particular standpoint. That standpoint, it will also be recognized, would not imply any claim of epistemological superiority over other standpoints. It would have no claim of absolute truth or knowledge of the truth. It would also have no claim of neutrality in assessing the virtues of liberalism against other non-liberal proposals to organize social institutions.

Rorty's views on neutrality should not be read as a form of scepticism or nihil-

overlap. However, for the purposes of this discussion, this account provides a rough and ready account of possible deviations from liberalism.

27 Here, 'sceptic' is meant as expressing scepticism of substantive liberal values.

28 This is consistent with Rorty's distinction between Philosophy and philosophy, which Nielsen also follows. In its 'big-p sense', "Philosophy" is an endeavour to uncover the nature of certain normative concepts, such as justice. See Nielsen, "Reply to Richard Rorty", supra note 1 at 132. By contrast, in its "little-p"sense, "philosophy" is a quest pursued by appealing as much as possible to concepts that are free-standing. For Rorty and Nielsen, the latter represents pragmatism. In this sense, philosophy can still provide justification on a given question, but it cannot have an overriding "justificatory role," because it does not offer a theory of justification. See Nielsen, "Reply to Richard Rorty" \& Nielsen, "Reply to Idil Boran", supra note 1.

29 Nielsen, "Wide Reflective Equilibria", supra note 3. 
ism, but rather as a particular approach to justification. What is distinctive about this approach is that contested philosophical claims (presumably about truth and knowledge) can be included in the reasoning. The reasoning would be pragmatic and would not require a theory of justification. Instead, imagination and narrative can be used to show how liberalism may present alternative visions of social order. It may then be possible to show that a liberal conception of justice would make the world a better place.

There is, however, something puzzling about the suggestion to use contested philosophical claims in the context of Rorty's express pragmatism. Many contested philosophical claims are claims about truth, sometimes absolute truth. If Rorty's pragmatism ends up allowing these claims, then it will defeat its own purpose. For Rorty's main point is that there is no such thing as detached, objective truth. If this is so, why engage in a debate by introducing such philosophical notions?

A reader sympathetic to Rorty might point out, however, that this objection rests on a misreading of Rorty's pragmatism. For Rorty, such an objector would clarify, there is no one absolute truth that has primacy over others. Thus, no special "vantage point" with special epistemic advantage available to assess truth claims. But this need not mean, Rorty's defender would add, that truth claims cannot be made or be used in discussions. We can use those claims in debates, but we must also concede that they have no special status over other claims. And we must also concede that there is no neutral way of assessing them.

But this reply, unfortunately, opens up further troubles. If there is no way of assessing different claims, then how do we know that new proposals present better alternatives? For even if a different world can be imagined, the process of imagination itself does not tell us why the imagined alternative is better than the existing situation. How can you tell, for example, that an imagined world would not turn out worse? How can you tell that it will present a better alternative? The only way to tell is to assess the proposed alternative in relation to a standard. ${ }^{30}$ An evaluation in relation to such a standard will tell us whether the alternative is better or worse, or whether it constitutes moral progress. Imagination without standards would generate empty statements at best. Any discussion would then quickly turn into a series of claims with each party insisting that their view is the right view to hold, and their alternative is the better alternative, with little hope of reaching a meaningful agreement.

Rorty's pragmatism, then, as attractive as it may be at first blush, is of little help for an external justification of liberalism's core commitment. But is Rawlsian constructivism as inadequate as Nielsen suggests? Nielsen turns to Rorty's pragmatism without exploring whether Rawlsian constructivism presents any such possibilities. Rawls himself does not offer a lengthy defence of liberalism for an external audience. But such a lack, I believe, can be remedied. In the following and final section, I wish to give some evidence for such possibility.

30 In Rorty, "Philosophy Relevant to Applied Ethics", supra note 14, Rorty refers to awareness of alternatives constituting progress because being aware of more alternatives makes us "wiser." $\mathrm{He}$ seems to treat this wisdom gained from awareness of alternatives as providing an evaluative basis. But this only makessense as an evaluative basis if it is construed as being grounded in some sort of theoretical value or standard. Thanks to Adam Rawlings for insights on this point. 


\section{LIBERALISM WITHOUT METAPHYSICS}

Rawls's views on method are based on Kantian constructivism ${ }^{31}$ in moral theory. This method consists in relating a particular conception of the person to principles of justice. Kantian constructivism, to be plausible, must work with a plausible conception of the person. But note that such a conception would not be an unrevisable one. A conception of the person is an empirical component of Kantian constructivism. It must, therefore, be revisable in light of new information. If new evidence showed that humans were constituted differently, then Kantian constructivism would have to take it seriously and modify its claims accordingly.

Such a useful account of the person has been offered by David Gauthier in his later writings. ${ }^{32}$ Human beings, Gauthier writes, share the capacity for a rich variety of intentional states as well as a linguistic capacity enabling them to represent these intentional states. The linguistic capacity allows people to include their intentional states among their objects of awareness, enabling them also to be aware of themselves as experiencing and acting subjects. Gauthier refers to this capacity as a sense of "inner space." 33 Possessing such a space, the individual can "distinguish and defend her beliefs, concerns, and attitudes in the face of quite different and even opposed beliefs, concerns, and attitudes that she ascribes to others." ${ }^{44}$ I will refer to this feature simply as 'internal awareness.'

Assuming that internal awareness is a plausible claim about humans, it can be used to shed light on the issue at hand. We can see those who reject substantive liberal values (such as individual freedom) as forming their rejection through an internal awareness of the beliefs, concerns, and attitudes they hold, giving rise to a vision of the sort of life they view as worthwhile. This awareness allows them to differentiate their beliefs, concerns, and attitudes from those held by others who do not share them. Possessing such a capacity, Nielsen's conservative sceptic wishes to pursue his life plans according to the beliefs and concerns that constitute his inner space.

An external justification of liberal institutional practices can also start from this capacity. To the extent that liberal institutions are put in place in recognition of this inner space, Nielsen's conservative sceptic can also recognize that he can pursue the sort of life he deems as the most worthwhile under liberal institutions. ${ }^{35}$ This is so to the extent that liberal institutions are designed, not on the

31 This can also be referred to as Kantian naturalism. In this discussion, I will not differentiate between these terms.

32 Gauthier articulates an understanding of a sense of justice based on Kantian naturalism in his later writings; see e.g. David Gauthier, "Value, Reasons, and the Sense of Justice" in R. G. Frey \& Christopher W. Morris, eds., Value, Welfare, and Morality (Cambridge: Cambridge University Press, 1993) [Gauthier, "Sense of Justice"], after the publication of David Gauthier, Morals by Agreement (Oxford: Oxford University Press, 1986). This conception of justice can and should be kept separate from the more widely known conception of justice based on rational agreement that he develops in Morals by Agreement.

33 Gauthier, "Sense of Justice", ibid., at 183.

34 Ibid.

35 Thus, through similar reasoning, accommodation of groups forming a minority (likely to be outnumbered by those who do not share their views) can be justified under liberal institutions. A 
rationale of imposing substantive values, but of honouring this internal awareness. Thus, he can be sceptical about substantive liberal values and yet pursue his values, within reason, under liberal institutions. Presented this way, liberalism's core commitment has plausibility, which should be amenable to those who reject its substantive commitments. So, Kantian constructivism does not require Nielsen's conservative sceptic to adopt substantive liberal values and is therefore not vulnerable to the common objection that liberalism smuggles in its substantive values, such as individual freedom or autonomy. The conservative sceptic may be as sceptical of these liberal values as he likes, but Kantian constructivism does not require him to hold any metaphysical truth other than his own. Nielsen's conservative sceptic can lead a life by his values and still benefit from liberal social practices.

It might be argued that Nielsen's conservative sceptic would be only reluctantly agreeing to the terms presented by liberalism. So, there is a potential problem, in that people may comply with a liberal institutional structure only because they cannot avoid it, not because they come to appreciate liberalism's core commitment. Rawls is concerned with this objection when he discusses whether political liberalism is more than a modus vivendi. ${ }^{36}$ Although a cynic may view it purely instrumentally, liberalism's core commitment can be grounded on a deeper sense of justice that relates to a conception of persons as subjects of internal awareness, and the recognition of this awareness as one of the deliverances of justice.

This is not to say, however, that the conservative sceptic need not make any compromise. It is not within the scope of this paper to discuss what exactly the limits of liberal agreement might be. But it should suffice to mention that living under a liberal institutional structure will entail certain constraints. Certain actions are clearly unacceptable. For example, actions that prevent others living their life according to their sense of internal awareness are wrong. But this follows from a broader sense of justice than just the liberal. As we become aware of our own internal intentional states, we also become aware that others have similar internal experiences. We also see that we live in a world of scarcity. Thus, we cannot fulfil all of our wishes and must engage in cooperation with others. This involves voluntarily accepting some constraints on our conduct with others, given that we must somehow negotiate between our internal experiences and

liberal defence of minority rights has been offered by Will Kymlicka. See especially Will Kymlicka, Liberalism, Community, Culture (Oxford: Oxford University Press, 1989) \& Will Kymlicka, Multicultural Citizenship (Oxford: Oxford University Press, 1995), where he maintains that liberalism can secure minority rights. However, in his arguments, Kymlicka does not endorse, but is critical of, the minimal form of liberalism, which Rawls calls "political liberalism" emphasized especially in his later writings. See especially Rawls, "Idea of an Overlapping Consensus", supra note 5 \& John Rawls, Political Liberalism (Cambridge, Mass.: Harvard University Press, 1993). See also Will Kymlicka, Contemporary Political Philosophy: An Introduction, 2d ed. (Oxford: Oxford University Press, 2002) at 232-236, 239-240. Kymlicka holds that Rawls's political liberalism cannot be a good strategy to accommodate communitarian minority groups. However, it is not within the scope of this paper to discuss whether Kymlicka's reading of political liberalism is the only option for conceptualizing its ideals and whether it presents as weak a case for accommodating minorities as Kymlicka suggests.

36 Rawls, "Idea of an Overlapping Consensus", supra note 5, 430. 
theirs. But to come to the awareness of the virtue of cooperation (and needed constraints) does not require adopting a narrow liberal view of individualism. On the contrary, it requires a sense of collective participation, of the sort the conservative might also endorse. Thus, someone with a sense of justice, broadly understood, must be someone who agrees to constraints.

Of course, some may still reject the entire justification presented thus far. But my aim here is not to show that liberalism's core commitment is a view no one could reject, but to put forward its plausibility, including its plausibility for an external audience. The appeal of liberalism's core commitment is that a conservative sceptic can still reject substantive liberal values and yet recognize, and even accept, the virtues of liberal institutions. Liberalism's core commitment, at least on Kantian constructivism, does not introduce any substantive individualism. Rather than appealing to individualism, it appeals to a sense of internal awareness, and the latter includes non-individualistic and community- or family-based values. To the extent that the conservative sceptic can reject individualism and yet wish to pursue his values, there are grounds for him to recognize the merits of an institutional structure that would allow him to do just that.

\section{CONCLUSION}

I tried to show in this paper that Kai Nielsen's appeal to Rorty for an external justification of liberalism faces a number of problems and that turning to Rorty's pragmatism is of little help. I have suggested that one such justification can be motivated from Kantian constructivism. Although I focused mostly on the shortcomings of Rorty's claims, there is nevertheless something to learn from his pragmatism. What emerges is that both Rawls and Rorty are striving to find a convincing way of discarding all things metaphysical and introducing a useful and practical way of thinking about justice that is capable of making the world a better place. The question, then, is not so much whether philosophers embarked on this project are "practical-minded" or anti-metaphysical, but how exactly they plan to dispense of metaphysics and what they hope to achieve as a result. How can philosophy be made genuinely practical, able to come to grips with current problems, and respond to them in a way that can be used, rather than merely contemplated? What brings Nielsen and I together is that we are also part of the same larger project. I have tried to show against Nielsen, however, that Rorty's pragmatism is insightful only in its broadest sense. Rawls's constructivism, if adequately developed, may be able to provide in greater detail what it takes to "travel philosophically light" (using Nielsen's words) in the long process of trying to figure out the requirements and deliverances of justice in a complex world. 